\title{
Efficiency of $\mathrm{CO}_{2}$ fixation by microalgae in a closed raceway pond
}

\author{
Shuwen $\mathrm{Li}^{\mathrm{a}, \mathrm{b}, \mathrm{c}}$, Shengjun Luo ${ }^{\mathrm{a}, *}$, Rongbo Guo ${ }^{\mathrm{a}, *}$ \\ ${ }^{a}$ Key Laboratory of Biofuels, Qingdao Institute of Bioenergy and Bioprocess Technology, Chinese Academy of Sciences, Qingdao 266101, PR China \\ ${ }^{\mathrm{b}}$ College of Life Sciences, Qingdao Agricultural University, Qingdao 266109, PR China \\ ${ }^{\mathrm{c}}$ University of Chinese Academy of Sciences, Beijing 100049, PR China
}

\section{H I G H L I G H T S}

- A closed raceway pond and its equation of $\mathrm{CO}_{2}$ mass transfer.

- $\mathrm{CO}_{2}$ dissolution efficiency in the closed raceway pond without algae.

- $\mathrm{CO}_{2}$ fixation efficiency by algae with continuous aeration in the pond.

- A mode of intermittent aeration with $\mathrm{CO}_{2}$ fixation efficiency of $95 \%$ in the pond.

\section{A R T I C L E I N F O}

\section{Article history:}

Received 3 December 2012

Received in revised form 4 March 2013

Accepted 6 March 2013

Available online 13 March 2013

\section{Keywords:}

Microalgae

Fixation efficiency

Mass transfer coefficient

Model

Intermittent gas sparging

\begin{abstract}
A B S T R A C T
Microalgae contain about $50 \%$ of carbon, which means that a total of 1.83 ton of $\mathrm{CO}_{2}$ is needed to produce 1 ton of microalgae. The cost of $\mathrm{CO}_{2}$ supply for microalgal large scale cultivation should be considered and the low $\mathrm{CO}_{2}$ fixation efficiency by microalgae will lead to much more expenditure of $\mathrm{CO}_{2}$. In this study, a closed raceway pond was constructed by covering a normal open raceway pond with a specially designed transparent cover, which directly touched the surface of microalgal culture media. This cover prevented supplied $\mathrm{CO}_{2}$ escaping into atmosphere and thus increased the retention time of $\mathrm{CO}_{2}$. The $\mathrm{CO}_{2}$ gas-liquid mass transfer and $\mathrm{CO}_{2}$ fixation efficiency by microalgae in the closed raceway pond were investigated, and the model of $\mathrm{CO}_{2}$ fixation by microalgae was developed. Through the model, the $\mathrm{CO}_{2}$ fixation efficiency increased to $95 \%$ under intermittent gas sparging.
\end{abstract}

(c) 2013 Elsevier Ltd. All rights reserved.

\section{Introduction}

Microalgae have received extensive research for five decades because of their possible commercial application in biofuels, cosmetics, pharmaceuticals, nutrition and food additives, aquaculture, pollution prevention, wastewater treatment and so on (Mata et al., 2010; Milledge, 2010; Spolaore et al., 2006). However, the high cost of microalgal cultivation is one of the greatest obstacles for commercial application. The availability and cost of $\mathrm{CO}_{2}$ are major factors in the economics of algal mass culture. It was estimated that the cost of carbon source ranged from about $8 \%$ to $27 \%$ of the production costs of the algae (Laws and Berning, 1991). The cost of carbon source will be multiplied with the lower $\mathrm{CO}_{2}$ fixation efficiency. There are many factors influencing $\mathrm{CO}_{2}$ fixation efficiency in microalgal cultivation, including microalgal strains, structures of photobioreactors, light quantity and quality, operating models and nutrition conditions. The structures of photobiore-

* Corresponding authors. Tel./fax: +86 53280662750 (S. Luo), tel.: +86 532 80662708; fax: +8653280662709 (R. Guo).

E-mail addresses: luosj@qibebt.ac.cn (S. Luo), guorb@qibebt.ac.cn (R. Guo). actors have an important effect on $\mathrm{CO}_{2}$ fixation efficiency because they affect $\mathrm{CO}_{2}$ dissolution efficiency and $\mathrm{CO}_{2}$ utilization efficiency by microalgae. Open-culture systems normally cannot use supplied $\mathrm{CO}_{2}$ effectively, which easily escaped from the culture media due to the shallow depths and poor $\mathrm{CO}_{2}$ mass transfer efficiency, and $\mathrm{CO}_{2}$ fixation efficiency ranged from $10 \%$ to $30 \%$ (Becker, 1994; Weissman and Goebel, 1985). This low efficiency results in microalgal cultivation cost intensive (Campbell et al., 2011). In order to improve $\mathrm{CO}_{2}$ fixation efficiency by microalgae in open raceway pond, Ketheesan and Nirmalakhandan (2012) designed an airlift-driven raceway reactor for microalgal cultivation with the maximum $\mathrm{CO}_{2}$ utilization efficiency of $33 \%$, and Putt et al. (2011) designed and investigated $\mathrm{CO}_{2}$ transfer efficiency of a carbonation column combining with open ponds without analyzing the energy consumption and the microalgal productivity in the photobioreactor. Compared with open culture systems, closed photobioreactors could reduce $\mathrm{CO}_{2}$ losses because they can prolong $\mathrm{CO}_{2}$ retention time and improve mass transfer efficiency. Many researchers have studied microalgal $\mathrm{CO}_{2}$ fixation with closed photobioreactors (Chiu et al., 2008; de Morais and Costa, 2007; Cheng et al., 2006; Keffer and Kleinheinz, 2002). But the $\mathrm{CO}_{2}$ fixation efficiency was not high, 
especially for the high concentration of $\mathrm{CO}_{2}$. Chiu et al. (2008) reported that the efficiency of $\mathrm{CO}_{2}$ removal by Chlorella sp. was $16 \%$ at $\mathrm{CO}_{2}$ concentration of $15 \%$, and in treatment of $2 \% \mathrm{CO}_{2}$ gas sparging, $\mathrm{CO}_{2}$ fixation efficiency was $58 \%$ in a semi-continuous photobioreactor. de Morais and Costa (2007) reported that the $\mathrm{CO}_{2}$ fixation efficiency was lower with high $\mathrm{CO}_{2}$ concentration (12\%) than that with low concentration (6\%). In the present study, a closed raceway pond was proposed and its structure can increase the $\mathrm{CO}_{2}$ retention time. Cheng et al. (2006) had demonstrated that increasing retention time of $\mathrm{CO}_{2}$ in photobioreactor will significantly enhance the $\mathrm{CO}_{2}$ fixation efficiency. The objective of this work was to investigate the $\mathrm{CO}_{2}$ fixation efficiency by microalgae at high $\mathrm{CO}_{2}$ concentration in the closed raceway pond and develop dynamic model of $\mathrm{CO}_{2}$ fixation, which is used to provide method for the improvement of $\mathrm{CO}_{2}$ fixation efficiency.

\section{Methods}

\subsection{Closed raceway pond (CRWP)}

The schematic diagram of the closed raceway pond is shown in Fig. 1. The CRWP was a four-channel raceway-type pond, being $1.2 \mathrm{~m}$ long, $0.25 \mathrm{~m}$ wide and $0.09 \mathrm{~m}$ deep, with each channel $0.06 \mathrm{~m}$ width. The CRWP had two parts and was made of polymethyl methacrylate. The bottom part of the CRWP was a rectangular box without top surface, and the cover part was H-shaped with the water clapboards attached to the lower surface of the cover. A paddle wheel was used for mixing and stirring of the culture medium. The enriched $\mathrm{CO}_{2}$ gas was aerated into the CRWP by a porous tube from $\mathrm{CO}_{2}$ inlet. As Fig. 1 shows, the H-shaped cover directly touched the culture liquid surface and kept gas bubbles going along with culture flow. The dashed line in Fig. 1 represents the surface of culture liquid, which touched the cover. The culture liquid was $0.04 \mathrm{~m}$ deep. The outlet of exhausted gas in CRWP was in the paddle wheel mixing zone. The arrows in channels represent the direction of culture flow.

\subsection{Microalgal cultivation}

Strain Chlorella vulgaris was obtained from College of Marine Life Sciences, Ocean University of China. Algal cells were cultivated in the following medium (per liter) (Li et al., 2012), containing $1000 \mathrm{mg} \mathrm{KNO}, 237 \mathrm{mg} \mathrm{KH} \mathrm{PO}_{4}, 88 \mathrm{mg} \mathrm{CaCl} 2 \cdot 2 \mathrm{H}_{2} \mathrm{O}, 40 \mathrm{mg}$ EDTA, $30 \mathrm{mg} \mathrm{FeSO} \cdot 7 \mathrm{H}_{2} \mathrm{O}, 204 \mathrm{mg} \mathrm{MgSO}_{4} \cdot 7 \mathrm{H}_{2} \mathrm{O}$, and $1 \mathrm{~mL}$ of trace metal solution. The trace metal solution (per liter) included $0.83 \mathrm{~g}$ $\mathrm{H}_{3} \mathrm{BO}_{3}, 0.17 \mathrm{~g}\left(\mathrm{NH}_{4}\right)_{6} \mathrm{Mo}_{7} \mathrm{O}_{24} \cdot 4 \mathrm{H}_{2} \mathrm{O}, 0.51 \mathrm{~g} \mathrm{CoCl} 2 \cdot 6 \mathrm{H}_{2} \mathrm{O}, 3.3 \mathrm{~g} \mathrm{MnCl}_{2-}$ $.4 \mathrm{H}_{2} \mathrm{O}, 0.95 \mathrm{~g} \mathrm{CuSO}_{4} \cdot 5 \mathrm{H}_{2} \mathrm{O}, 2.7 \mathrm{~g} \mathrm{ZnSO}_{4} \cdot 7 \mathrm{H}_{2} \mathrm{O}$. The flow velocity of culture medium in CRWP was $0.03 \mathrm{~m} \mathrm{~s}^{-1}$ with $12 \mathrm{~L}$ working volume. Culture was aerated continuously (or intermittently) with $15 \% \mathrm{CO}_{2}$ at different gas flow rates, and the gas flow rate was mea- sured using a quality flow meter (LZB-3, Yinhuan, China). The microalgal cells were incubated at $24 \pm 1{ }^{\circ} \mathrm{C}$ under the light intensity of $100 \mu \mathrm{mol} \mathrm{m}^{-2} \mathrm{~s}^{-1}$ with continuous light, and the light intensity was determined using a light meter (Hansatech Instruments Quantitherm light meter thermometer, Norfolk, England). The $\mathrm{pH}$ value of culture was measured using a pH meter (PB-10, Sartorius, Germany) and the concentration of dissolved oxygen (DO) in culture was determined using a DO meter (M700, Mettler Toledo, Switzerland). The dissolved $\mathrm{CO}_{2}$ concentration in media was determined by a $\mathrm{CO}_{2}$ meter (FC-200, Shanghai su park information technology Co. Ltd., China).

Culture suspension with a volume of $30 \mathrm{~mL}$ was filtered through pre-dried and pre-weighted $2 \mu \mathrm{m}$ membrane filters, after filtration the filter was rinsed with distilled water, and the filter with microalgal cells was dried at $105^{\circ} \mathrm{C}$ in an oven overnight. The filter was removed from the oven, kept in a desiccator and reweighted. This weight minus the weight of the empty filter gave the biomass density. Samples were generally run in triplicate for each data point. The biomass productivity $\left(P, \mathrm{~g} \mathrm{~L}^{-1} \mathrm{~d}^{-1}\right)$ of microalgae was calculated from the variation in biomass density $\left(X, \mathrm{~g} \mathrm{~L}^{-1}\right)$ according to the equation $P=\frac{X_{t}-X_{0}}{t-t_{0}}$, where $X_{0}$ was the initial biomass density at time $t_{0}$ and $X_{t}$ was the biomass density at any time $t$ subsequent to $t_{0}$.

\subsection{Calculation of $\mathrm{CO}_{2}$ volumetric mass transfer coefficient}

The CRWP containing 12 L media without microalgal cultivation was aerated with different concentrations of $\mathrm{CO}_{2}(1.2 \%, 2 \%, 15 \%$, $100 \%(\mathrm{v} / \mathrm{v})$ with $\mathrm{N}_{2}$ balance) for $120 \mathrm{~min}$ at $24 \pm 0.5{ }^{\circ} \mathrm{C}$. The liquid velocity ( $v_{\text {wat }}$ ) was $0.03 \mathrm{~m} \mathrm{~s}^{-1}$ and the dissolved $\mathrm{CO}_{2}$ concentration in culture media was recorded every five minutes. According to two-film theory (Carvalho et al., 2006) and Henry's law, the volumetric mass transfer coefficient of $\mathrm{CO}_{2}$ in media was calculated from the following equation:

$$
\frac{d C}{d t}=K_{L} a\left(C^{*}-C\right)
$$

$\frac{d C}{d t}$, volumetric transport rate of $\mathrm{CO}_{2}$ in liquid $\left(\mathrm{mol} \mathrm{min}^{-1} \mathrm{~L}^{-1}\right) ; K_{L} a$, volumetric mass transfer coefficient of $\mathrm{CO}_{2}\left(\mathrm{~min}^{-1}\right)$; $\mathrm{C}^{*}$, concentration of $\mathrm{CO}_{2}$ in culture in equilibrium with $\mathrm{CO}_{2}$ content in $\mathrm{CO}_{2}$ bubbles $\left(\mathrm{mol} \mathrm{L}^{-1}\right)$, which can be determined via Henry's Law; $C, \mathrm{CO}_{2}$ concentration in culture media $\left(\mathrm{mol} \mathrm{L}^{-1}\right)$.

Integration for $C=C_{0}$ at $t=0$, led to the following equation:

$\ln \frac{C^{*}-C}{C^{*}-C_{0}}=-K_{L} a t$

A plot of left hand side of this equation against time was used to obtain $-K_{L} a$ as the slope.

(a)

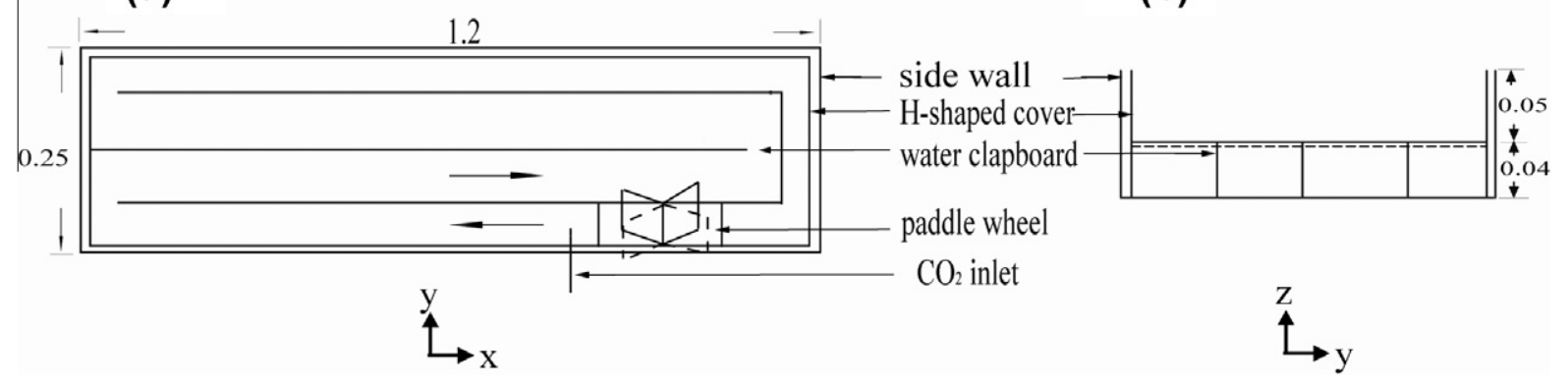

Fig. 1. The schematic diagram of the closed raceway pond (a): top view of the closed raceway pond; (b): side view of the closed raceway pond. 


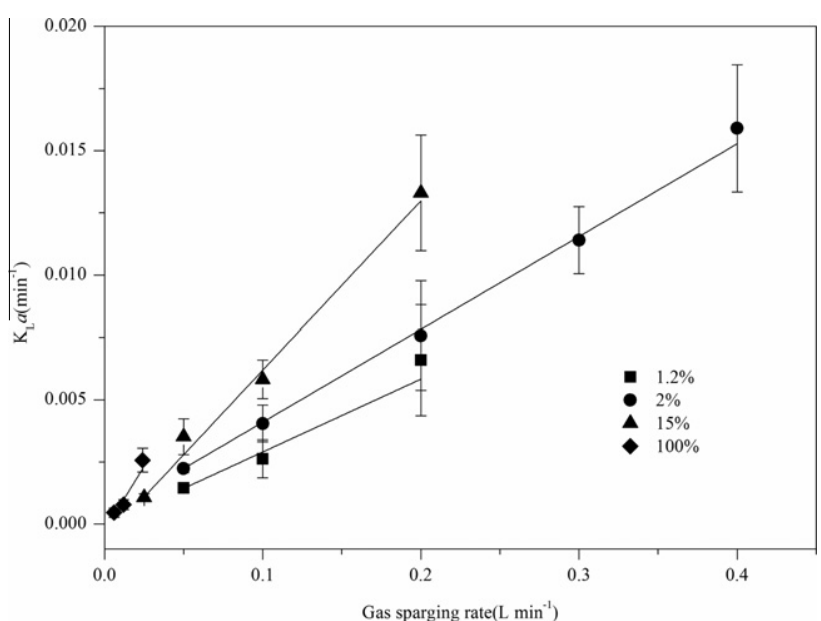

Fig. 2. The relation between gas sparging rate and $K_{L} a$.

\section{Results and discussion}

\section{1. $\mathrm{CO}_{2}$ volumetric mass transfer and dissolution efficiency in CRWP}

The $\mathrm{CO}_{2}$ volumetric mass transfer coefficients of different concentrations of $\mathrm{CO}_{2}$ in culture media in CRWP aerated with different rates are shown in Fig. 2 . With the same gas sparging rate, $K_{L} a$ increased with the increase of $\mathrm{CO}_{2}$ concentrations. Under the same $\mathrm{CO}_{2}$ concentration, $K_{L} a$ was proportional to gas sparging rate. A linear regression equation between $K_{L} a$ and gas sparging rate $(Q)$ can be obtained:

$K_{L} a=A Q$

where $Q$ is the volumetric flow rate of gas $\left(\mathrm{L} \mathrm{min}^{-1}\right)$ and $A$ is a coefficient.
The $A$ value at $\mathrm{CO}_{2}$ concentrations of $1.2,2,15$, and $100 \%$ was $0.031\left(R^{2}=0.9894\right), 0.039\left(R^{2}=0.9991\right), 0.065\left(R^{2}=0.9944\right), 0.097$ $\left(R^{2}=0.9568\right)$, respectively. Integration of Eqs. (1) and (2) led to:

$\frac{d C}{d t}=A\left(C^{*}-C\right) Q$

The transport rate of $\mathrm{CO}_{2}$ in CRWP aerated with different gas flow rates and $\mathrm{CO}_{2}$ concentrations can be calculated from Eq. (3).

According to Eq. (3), when the change of $\left(C^{*}-C\right)$ can be neglected in short time, the number of mole of dissolved $\mathrm{CO}_{2}$ $\left(n_{\mathrm{CO}_{2}-\mathrm{dis}}, \mathrm{mol}\right)$ in culture media can be expressed as follows:

$n_{\mathrm{CO}_{2}-\mathrm{dis}}=A\left(C^{*}-C\right) Q t V$

where $t$ is the gas sparging time ( $\min$ ) and $V$ is the volume of culture media (L).

The number of mole of $\mathrm{CO}_{2}$ supply $\left(n_{\mathrm{CO}_{2}-\text { sup }}\right.$, mol) can be determined from the following equation:

$n_{\mathrm{CO}_{2}-\mathrm{sup}}=\frac{\mathrm{Qtp}}{M}$

where $p$ is the $\mathrm{CO}_{2}$ concentration, and $\mathrm{M}$ is the molar volume of $\mathrm{CO}_{2}$ $\left(\mathrm{mol} \mathrm{L}^{-1}\right)$ and is calculated by the following equation:

$M=\frac{22.4 \times(273+T)}{273}$

where $T$ is the culture temperature $\left({ }^{\circ} \mathrm{C}\right)$.

The calculated $\mathrm{CO}_{2}$ dissolution efficiency $(\eta)$ in CRWP was obtained:

$\eta=\frac{n_{\mathrm{CO}_{2} \text {-dis }}}{n_{\mathrm{CO}_{2}-\text { sup }}}=\frac{A\left(C^{*}-C\right) V M}{p}$

According to Eq. (4), the $\mathrm{CO}_{2}$ dissolution efficiency in CRWP without microalgae can be calculated. Fig. 3 shows the relationship of dissolved $\mathrm{CO}_{2}$ concentration in media and $\mathrm{CO}_{2}$ dissolution efficiency. The maximal mean relative error between the experimental

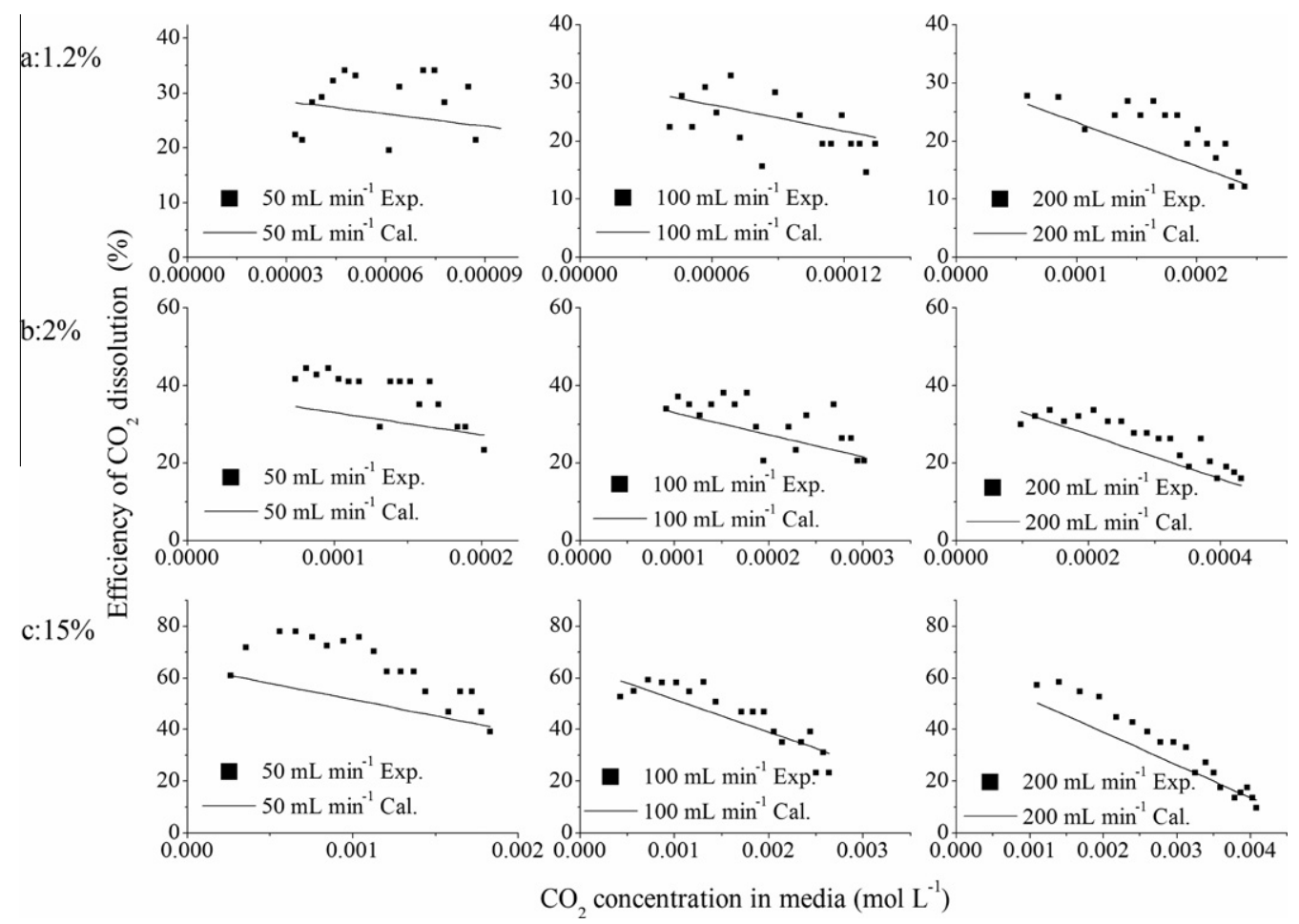

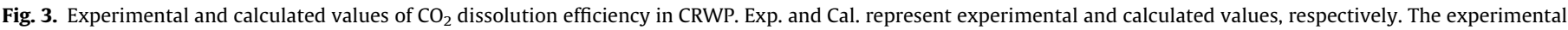
values were determined from the following equation: $\frac{C_{\mathrm{var}} V}{n_{\mathrm{CO}_{2}-\text { sup }}}$, where $C_{\mathrm{var}}$ was the variation of $\mathrm{CO}_{2}$ concentration in media in five minutes (mol $\mathrm{L}^{-1}$ ). 
Table 1

Microalgal productivity and $\mathrm{CO}_{2}$ fixation efficiency with different gas flow rates.

\begin{tabular}{lll}
\hline $\begin{array}{l}\text { Gas flow rate } \\
\left(\mathrm{L} \mathrm{min}^{-1}\right)\end{array}$ & $\begin{array}{l}\text { Microalgal productivity } \\
\left(\mathrm{g} \mathrm{d}^{-1} \mathrm{~L}^{-1}\right)\end{array}$ & $\begin{array}{l}\mathrm{CO}_{2} \text { fixation efficiency } \\
(\%)^{\mathrm{a}}\end{array}$ \\
\hline 0.025 & $0.2349 \pm 0.0168$ & 53 \\
0.035 & $0.3496 \pm 0.0117$ & 56 \\
0.05 & $0.3219 \pm 0.0109$ & 36 \\
\hline
\end{tabular}

a The $\mathrm{CO}_{2}$ fixation efficiency was calculated as follows: $\frac{0.5 P V}{12 \times 60 \times 24 \times n_{\mathrm{CO}}-\mathrm{sup}} \times 100 \%$, where $0.5,12,60$ and 24 represent carbon percentage content in dried microalgae, carbon molecular weight, minutes in an hour and hours in a day, respectively.

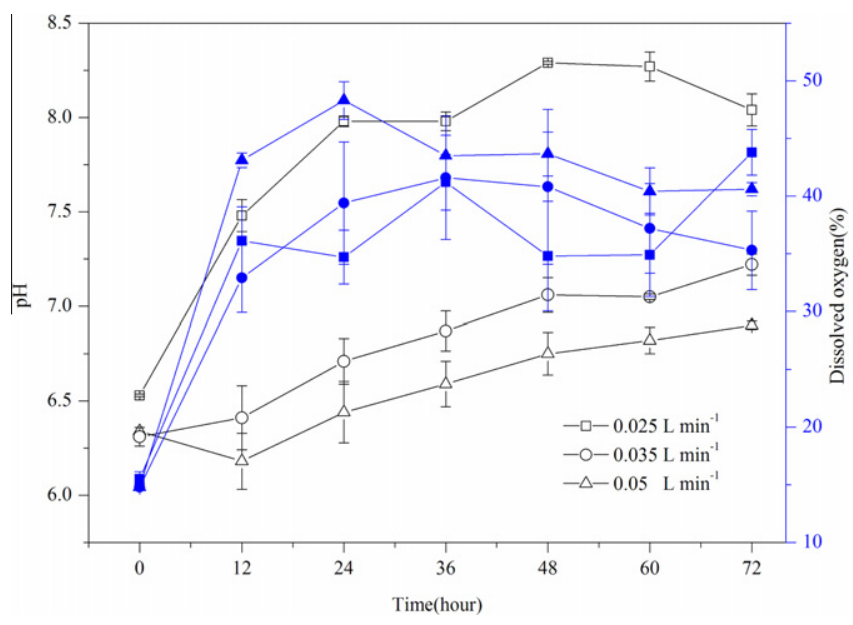

Fig. 4. The pH values and DO levels of culture in CRWP. Open and closed symbols represent $\mathrm{pH}$ values and $\mathrm{DO}$ levels of culture, respectively.

and calculated values of dissolution efficiency was $14 \%$, which showed a goodness of fit of the equation. As shown in Eq. (4), the efficiency of $\mathrm{CO}_{2}$ dissolution in the CRWP aerated with certain $\mathrm{CO}_{2}$ concentration had no relation with gas sparging rate and may be determined by the characteristics of CRWP, including the structure of photobioreactor, liquid velocity, mixing time and temperature, which influenced the overall volumetric mass transfer coefficient and hydrodynamics characteristics (Ugwu et al., 2008). The maximal $\mathrm{CO}_{2}$ dissolution efficiency of media in CRWP aerated with $15 \% \mathrm{CO}_{2}$ was $64 \%$ according to Eq. (4), which was the maximal $\mathrm{CO}_{2}$ fixation efficiency by microalgae under continuous $\mathrm{CO}_{2}$ supply because microalgae can only utilize dissolved $\mathrm{CO}_{2}$ and change it into biomass.

\subsection{Microalgal productivity and $\mathrm{CO}_{2}$ fixation efficiency with continuous gas sparging}

The microalgal productivity and $\mathrm{CO}_{2}$ fixation efficiency in CRWP under the concentration of $15 \% \mathrm{CO}_{2}$ with different gas flow rates are shown in Table 1 . The changes of $\mathrm{pH}$ values and DO levels of culture during microalgal growth are shown in Fig. 4. As shown in Fig. 4, for 0.035 and $0.05 \mathrm{~L} \mathrm{~min}^{-1}$, the $\mathrm{pH}$ values of culture ranged from $6.18 \pm 0.14$ to $7.22 \pm 0.05$, which did not inhibit microalgal growth (Hodaifa et al., 2010), and the levels of DO varied from $14.8 \pm 0.1 \%$ to $48.3 \pm 1.6 \%$ during cultivation. Although the oxygen build-up in photobioreactors would lead to photorespiration and even photo-oxidation with high levels of irradiance (Douskova et al., 2009; Miron et al., 1999), the competitive inhibition of ribulose-1,5-bisphosphate carboxylase by oxygen gradually became weak with the increase of concentration of $\mathrm{CO}_{2}$ when oxygen level ranged from $20 \%$ to $50 \%$ (Aiba, 1982). In the present study, because the microalgal culture was aerated with high concentration of $\mathrm{CO}_{2}$ $\left(15 \% \mathrm{CO}_{2}\right)$, and illuminated with low light intensity $\left(100 \mu \mathrm{mol} \mathrm{m}{ }^{-2-}\right.$

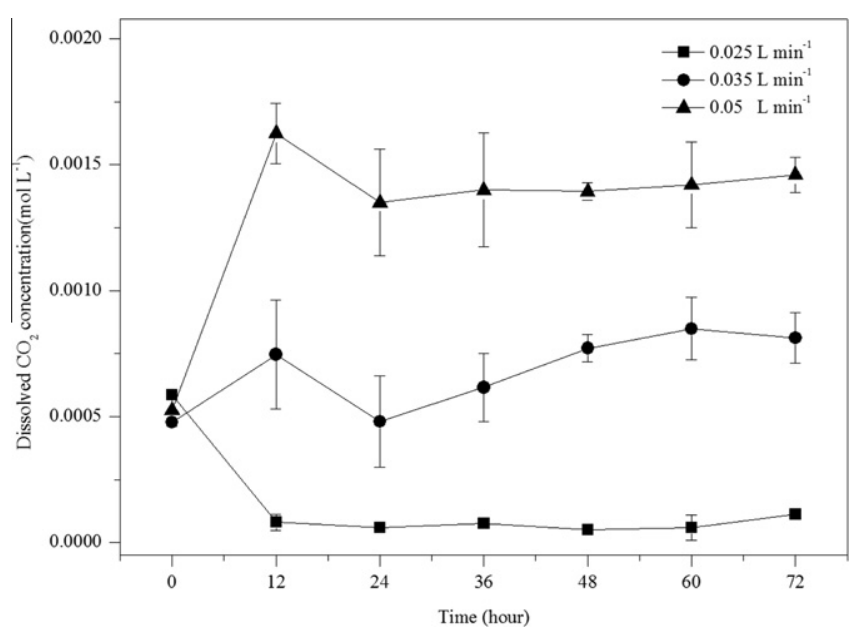

Fig. 5. Dissolved $\mathrm{CO}_{2}$ concentrations in culture with different gas sparging rates.

$\mathrm{s}^{-1}$ ), the inhibition action of oxygen accumulation to microalgal growth in the CRWP did not be found. Therefore, the culture $\mathrm{pH}$ and DO level in CRWP did not inhibit microalgal growth with the gas sparging rates of 0.035 and $0.05 \mathrm{~L} \mathrm{~min}^{-1}$. Fig. 5 gives the change of dissolved $\mathrm{CO}_{2}$ concentration in culture aerated with different gas sparging rates. As shown in Fig. 5, the average dissolved $\mathrm{CO}_{2}$ concentrations in microalgal culture aerated with the gas sparging rates of $0.025,0.035$ and $0.05 \mathrm{~L} \mathrm{~min}^{-1}$ from 12 to $72 \mathrm{~h}$ were 73 , 713 and $1441 \mu \mathrm{mol} \mathrm{L}^{-1}$, respectively. The microalgal productivity in CRWP aerated with the gas sparging rate of $0.025 \mathrm{~L} \mathrm{~min}^{-1}$ was obviously lower than that of other gas flow rates, which showed that the dissolved $\mathrm{CO}_{2}$ amounts cannot satisfy microalgal growth. Weissman et al. (1988) observed that $\mathrm{CO}_{2}$ concentration in bulk liquid of at least $65 \mu \mathrm{mol} \mathrm{L}^{-1}$ and $\mathrm{pH} 8.5$ were required for optimal productivity of some microalgae, but in the present study, $\mathrm{CO}_{2}$ concentration of $73 \mu \mathrm{mol} \mathrm{L}^{-1}$ in media and $\mathrm{pH} 8$ (shown in Fig. 4) cannot meet microalgal normal growth. The difference may be determined by algal species. For 0.035 and $0.05 \mathrm{~L} \mathrm{~min}^{-1}$, with the increase of gas flow rate, the concentration of dissolved $\mathrm{CO}_{2}$ in culture increased and the $\mathrm{CO}_{2}$ fixation efficiency decreased, which indicated that much of $\mathrm{CO}_{2}$ supply was wasted with continuous supply. According to Eq. (4), the maximal microalgal productivity in CRWP aerated with gas flow rates of 0.035 and $0.05 \mathrm{~L} \mathrm{~min}^{-1}$ should be 0.3970 and $0.5670 \mathrm{~g} \mathrm{~d}^{-1} \mathrm{~L}^{-1}$, respectively, but the experimental microalgal productivity was 0.3496 and $0.3219 \mathrm{~g} \mathrm{~d}^{-1} \mathrm{~L}^{-1}$, respectively, which also indicated that some of supplied $\mathrm{CO}_{2}$ was wasted.

\section{3. $\mathrm{CO}_{2}$ fixation efficiency by microalgae with intermittent gas sparging}

With continuous gas sparging rates of 0.035 and $0.05 \mathrm{~L} \mathrm{~min}^{-1}$, the fixation efficiency was $56 \%$ and $36 \%$, respectively. According to Eq. (4), even the dissolved $\mathrm{CO}_{2}$ was completely fixed by microalgae, the maximal $\mathrm{CO}_{2}$ fixation efficiency in CRWP aerated with $15 \% \mathrm{CO}_{2}$ was $64 \%$, which indicated there were much $\mathrm{CO}_{2}$ escaped from CRWP. The method to further improve $\mathrm{CO}_{2}$ fixation efficiency in CRWP was to increase the length of raceway, which would prolong the residence time of $\mathrm{CO}_{2}$ in CRWP, or supply $\mathrm{CO}_{2}$ intermittently. In this work, the later was further studied. In order to reach the maximal $\mathrm{CO}_{2}$ fixation efficiency of $100 \%$, the amounts of supplied $\mathrm{CO}_{2}$ should completely dissolve in culture, and meanwhile, the dissolved $\mathrm{CO}_{2}$ met microalgal growth' need. Therefore, the relation between the gas sparging time $\left(t_{\mathrm{aer}}\right)$, the stopping time $\left(t_{\mathrm{sto}}\right), \mathrm{CO}_{2}$ dissolution rate in gas sparging $\left(v_{\mathrm{dis}}\right)$ and stopping $\left(v_{\mathrm{res}}\right)$ 


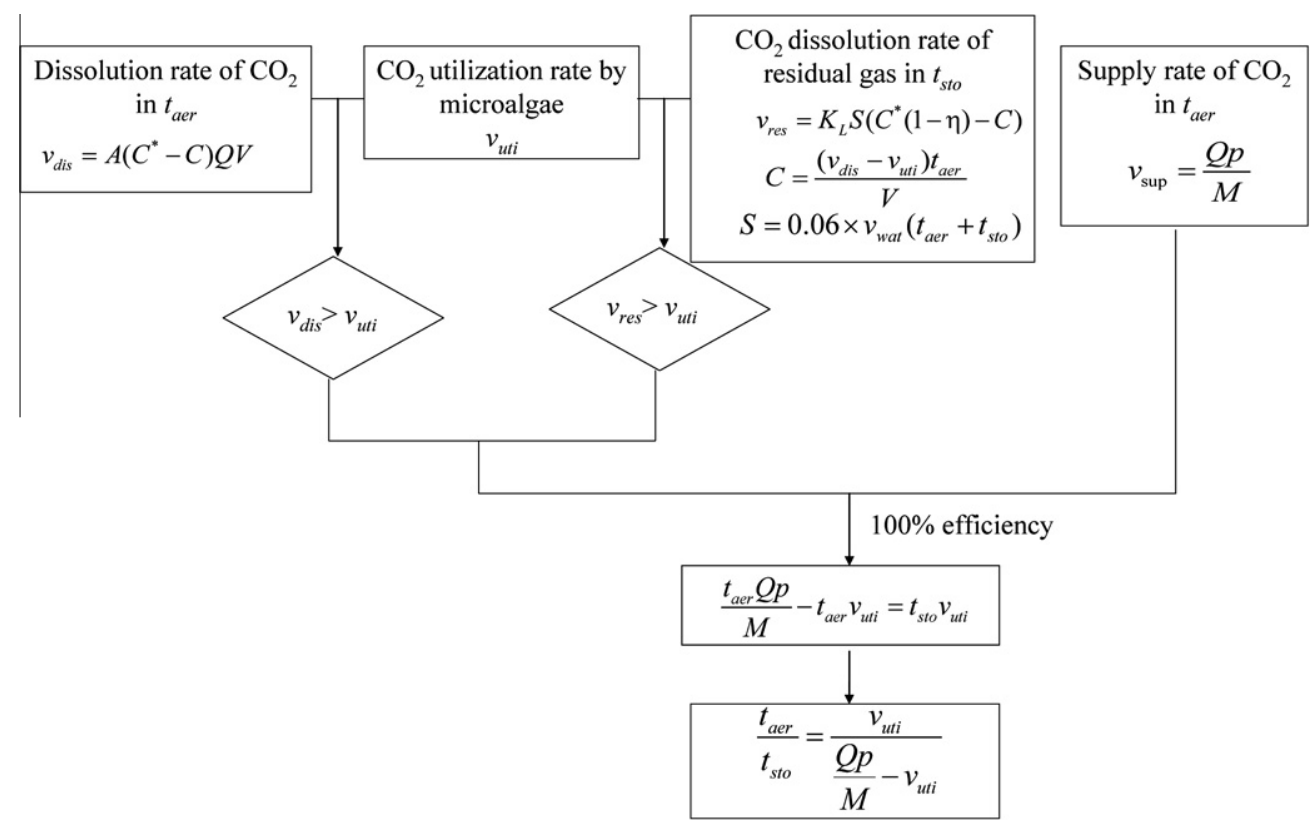

Fig. 6. The calculation model of intermittent time ( 0.06 is the width of each channel in the closed raceway pond).

time and the rate of $\mathrm{CO}_{2}$ utilization $\left(v_{\mathrm{uti}}\right)$ by microalgae should be studied. In the stopping time, the remaining $\mathrm{CO}_{2}$ (including $\mathrm{CO}_{2}$ in culture and residual gas) should be enough for microalgal growth, and $\mathrm{CO}_{2}$ in residual gas could dissolve completely in culture in $t_{\text {sto }}$. The dissolution rate of $\mathrm{CO}_{2}$ in residual gas $\left(v_{\text {res }}\right)$ can be expressed as follows:

$v_{\text {res }}=K_{L} S\left(C^{*}(1-\eta)-C\right)$,

where $K_{L}$ is equal to $0.0096 \mathrm{~m} \mathrm{~min}^{-1}$ (Shah et al., 1982) and $S$ is the surface area of residual gas bubble in CRWP.

In the gas sparging time, $\mathrm{CO}_{2}$ dissolution rate $\left(v_{\mathrm{dis}}\right)$ can be calculated from Eq. (3), and the average microalgal productivity $(P)$ can be used to calculate the rate of $\mathrm{CO}_{2}$ utilization $\left(v_{\text {uti }}\right)$ by microalgae. Fig. 6 gives the calculation model of intermittent time. For example, under the gas flow rate of $0.035 \mathrm{~L} \mathrm{~min}^{-1}$ with $15 \% \mathrm{CO}_{2}$ at $24{ }^{\circ} \mathrm{C}$, the average microalgal productivity was $0.3496 \mathrm{~g} \mathrm{~d}^{-1} \mathrm{~L}^{-1}$ with continuous gas sparging (shown in Table 1 ). Through calculating, the dissolution rate of $\mathrm{CO}_{2}\left(v_{\mathrm{dis}}\right)$ was greater than the utilization rate of $\mathrm{CO}_{2}$ by microalgae $\left(v_{\text {uti }}\right)$ in the gas sparging time, and in the stopping time, $v_{\text {res }}$ was far greater than $v_{\text {uti }}$, which indicated that the utilization rate of $\mathrm{CO}_{2}$ by microalgae was the rate-limiting step for $\mathrm{CO}_{2}$ absorption and the stopping time $\left(t_{\text {sto }}\right)$ was determined by the utilization rate of $\mathrm{CO}_{2}$ by microalgae $\left(v_{\mathrm{uti}}\right)$ in the intermittent operation. Therefore, the amounts of $\mathrm{CO}_{2}$ supply in the gas sparging time should be equal to that of $\mathrm{CO}_{2}$ of microalgal utilization in the gas sparging and stopping time, which gives:

$\frac{t_{\mathrm{aer}} Q p}{M}=t_{\mathrm{aer}} v_{\mathrm{uti}}+t_{\mathrm{sto}} v_{\mathrm{uti}}$

For the gas sparging rate of $0.035 \mathrm{~L} \mathrm{~min}^{-1}$ in CRWP, the proportion of $t_{\mathrm{aer}}$ to $t_{\text {sto }}$ was closed to 1 . The batch microalgal culture with the gas sparging time of $10 \mathrm{~s}$ and the stopping time of $10 \mathrm{~s}$ was investigated. After five days of cultivation, the average microalgal productivity was $0.2935 \pm 0.0023 \mathrm{~g} \mathrm{~d}^{-1} \mathrm{~L}^{-1}$, which indicated that the $\mathrm{CO}_{2}$ fixation efficiency by microalgae reached 95\% in CRWP with intermittent gas sparging. Compared with continuous supply of $\mathrm{CO}_{2}$, the intermittent gas sparging decreased the amounts of $\mathrm{CO}_{2}$ supply and meanwhile the amounts met microalgal growth' need, which improved the fixation efficiency. The values of $t_{\mathrm{aer}}$ and $t_{\text {sto }}$ should be further analyzed. Under intermittent gas sparging, with the utilization of $\mathrm{CO}_{2}$ by microalgae, the supplied $\mathrm{CO}_{2}$ should com- pletely dissolve in culture before running out of the CRWP, which meant that $t_{\mathrm{aer}}$ should be shorter than the residence time of $\mathrm{CO}_{2}$ in CRWP with continuous supply, and on the other hand, the shorter of $t_{\mathrm{aer}}$ and $t_{\mathrm{sto}}$, the faster of dissolution rate of $\mathrm{CO}_{2}$ in culture, which benefitted the $\mathrm{CO}_{2}$ fixation by microalgae. However, the microalgal productivity should be determined previously. Microalgal productivity can be predicted depending on light transfer with rich nutrition in medium (Fouchard et al., 2009; Yun and Park, 2003). Through the relationship between microalgal productivity, light distribution and $\mathrm{CO}_{2}$ dissolution rate, the proportion of $t_{\mathrm{aer}}$ to $t_{\text {sto }}$ can be calculated.

\section{Conclusions}

In this work, the $\mathrm{CO}_{2}$ mass transfer, dissolution efficiency and $\mathrm{CO}_{2}$ fixation efficiency by microalgae in the closed raceway pond were investigated. The dynamic equation for $\mathrm{CO}_{2}$ dissolution and the method of improving $\mathrm{CO}_{2}$ fixation efficiency by microalgae were developed. The experimental results showed that the developed model provided the guide for the improvement of $\mathrm{CO}_{2}$ fixation efficiency by microalgae. Through the developed model, under intermittent operation (10 s:10 s), the fixation efficiency reached $95 \%$. The concrete time of intermittent operation with different $\mathrm{CO}_{2}$ partial pressures and gas flow rates should be further studied.

\section{Acknowledgements}

This study was funded by National Natural Science Foundation (Nos. 31101918 and 41276143) and Shandong Province Science \& Technology Development Project (Nos. 2011GHY11531 and 2010GHY10504) and Natural Science Foundation of Shandong Province (Nos. Y2008F45 and ZR2012CL23).

\section{References}

Aiba, S., 1982. Growth kinetics of photosynthetic microorganisms. Adv. Biochem. Eng. 23, 85-156.

Becker, E.W., 1994. Microalgae Biotechnology and Microbiology. Cambridge University Press.

Campbell, P.K., Beer, T., Batten, D., 2011. Life cycle assessment of biodiesel production from microalgae in ponds. Bioresour. Technol. 102, 50-56. 
Carvalho, A.P., Meireles, L.A., Malcata, F.X., 2006. Microalgal reactors: a review of enclosed system designs and performances. Biotechnol. Prog. 22, 1490-1506.

Cheng, L., Zhang, L., Chen, H., Gao, C., 2006. Carbon dioxide removal from air by microalgae cultured in a membrane-photobioreactor. Sep. Purif. Technol. 50, 324-329.

Chiu, S.-Y., Kao, C.-Y., Chen, C.-H., Kuan, T.-C., Ong, S.-C., Lin, C.-S., 2008. Reduction of $\mathrm{CO}_{2}$ by a high-density culture of Chlorella sp. in a semicontinuous photobioreactor. Bioresour. Technol. 99, 3389-3396.

de Morais, M.G., Costa, J.A.V., 2007. Biofixation of carbon dioxide by Spirulina sp. and Scenedesmus obliquus cultivated in a three-stage serial tubular photobioreactor. J. Biotechnol. 129, 439-445.

Douskova, I., Doucha, J., Livansky, K., Machat, J., Novak, P., Umysova, D., Zachleder V., Vitova, M., 2009. Simultaneous flue gas bioremediation and reduction of microalgal biomass production costs. Appl. Microbiol. Biotechnol. 82, 179-185.

Fouchard, S., Pruvost, J., Degrenne, B., Titica, M., Legrand, J., 2009. Kinetic modeling of light limitation and sulfur deprivation effects in the induction of hydrogen production with Chlamydomonas reinhardtii: Part I. Model development and parameter identification. Biotechnol. Bioeng. 102, 232-245.

Hodaifa, G., Martínez, M.E. Sánchez, S., 2010. Influence of pH on the culture of Scenedesmus obliquus in olive-mill wastewater. Biotechnol. Bioprocess Eng. 14, 854-860.

Keffer, J.E., Kleinheinz, G.T., 2002. Use of Chlorella vulgaris for $\mathrm{CO}_{2}$ mitigation in a photobioreactor. J. Ind. Microbiol. Biotechnol. 29, 275-280.

Ketheesan, B., Nirmalakhandan, N., 2012. Feasibility of microalgal cultivation in a pilot-scale airlift-driven raceway reactor. Bioresour. Technol. 108, 196-202.

Laws, E.A., Berning, J.L., 1991. A study of the energetics and economics of microalgal mass culture with the marine chlorophyte Tetraselmis suecica: implications for use of power plant stack gases. Biotechnol. Bioeng. 37, 936-947.
Li, S.W., Luo, S.J., Guo, R.B., 2012. Influence of carbon dioxide concentration on microalgal growth in a bubble bolumn photobioreactor. Adv. Mater. Res. 599, 137-140.

Mata, T.M., Martins, A.A., Caetano, N.S., 2010. Microalgae for biodiesel production and other applications: a review. Renew. Sust. Energy Rev. 14, 217-232.

Milledge, J.J., 2010. Commercial application of microalgae other than as biofuels: a brief review. Rev. Environ. Sci. Biotechnol. 10, 31-41.

Miron, A.S., Gomez, A.C., Camacho, F.G., Grima, E.M., Chisti, Y., 1999. Comparative evaluation of compact photobioreactors for large-scale monoculture of microalgae. J. Biotechnol. 70, 249-270.

Putt, R., Singh, M., Chinnasamy, S., Das, K.C., 2011. An efficient system for carbonation of high-rate algae pond water to enhance $\mathrm{CO}_{2}$ mass transfer. Bioresour. Technol. 102, 3240-3245.

Shah, Y., Kelkar, B.G., Godbole, S., Deckwer, W.D., 1982. Design parameter estimations for bubble column reactors. AIChE J. 28, 353-379.

Spolaore, P., Joannis-Cassan, C., Duran, E., Isambert, A., 2006. Commercial applications of microalgae. J. Biosci. Bioeng. 101, 87-96.

Ugwu, C.U., Aoyagi, H., Uchiyama, H., 2008. Photobioreactors for mass cultivation of algae. Bioresour. Technol. 99, 4021-4028.

Weissman, J.C., Goebel, R.P., Benemann, J.R., 1988. Photobioreactor design: mixing, carbon utilization, and oxygen accumulation. Biotechnol. Bioeng. 31, 336-344.

Weissman, J.C., Goebel, R.P., 1985. Production of Liquid Fuels and Chemicals by Microalgae. Solar Energy Research Institute, Golden, Co., SERI/STR-231-2649.

Yun, Y.S., Park, J.M., 2003. Kinetic modeling of the light-dependent photosynthetic activity of the green microalga Chlorella vulgaris. Biotechnol. Bioeng. 83, 303311. 